\title{
Overburden stockpile revegetation techniques at PT Freeport Indonesia Grasberg Mine
}

\author{
J.M. Prewitt Freeport McMoRan Copper and Gold, USA
}

P. Puradyatmika PT Freeport Indonesia, Indonesia

\begin{abstract}
PT Freeport Indonesia (PTFI) operates the Grasberg open pit mine in the Indonesian province of Papua producing copper and gold concentrate. The Grasberg pit began operation in 1989 and is currently planned to transition to an underground operation in 2017. By the time of the transition to underground operations, over three billion tonnes of overburden will have been placed in the overburden stockpiles surrounding the open pit. This paper briefly describes the layout of the stockpiles and processes in place to ensure geotechnical and geochemical stability of the stockpiles, but focuses on revegetation techniques for reclamation.

PTFI practices concurrent reclamation of overburden stockpiles as areas reach final configuration and has already reclaimed over 260 hectares of land surface area using native plants suitable to the alpine location. Reclamation plans, techniques and costs are covered by Five Year Reclamation Plans that are submitted to the government of Indonesia for approval. Progress is verified annually by Ministry of Energy and Mineral Resources (MEMR) inspectors. Successful completion of the planned revegetation is required to release the funds set aside based on the Five Year Reclamation Plans.

Plants, seeds and mosses are harvested from surrounding areas and prepared in a nursery operated at the mining area. A tissue culture technique to produce additional seeds and seedlings is also being trialled at Grasberg and is the subject of a separate paper at this conference. Transplanted plants and seedlings are allowed to acclimate to the alpine climate conditions in the nursery before being planted on the overburden stockpiles. A combination of organic compost, both produced onsite and purchased from offsite, and commercially available fertilisers are used to promote the plant growth. Soil availability is severely limited at the mine elevation and a limestone fines material is used as a soil substitute to allow placement of the plants, especially on the slopes. Overburden slopes are designed at 2H:1V overall with slope faces generally at angle of repose interspersed with flat benches. Transplanting on the slopes requires special techniques and training of personnel to ensure personnel safety as well as viability of the vegetation. In addition to transplanting, hydroseeding is used to assist in full vegetative coverage.
\end{abstract}

Monitoring of reclamation areas includes soil sampling, evaluation of erosion, plant viability surveys, and evaluation of biodiversity of flora and fauna. The biodiversity of reclaimed areas is compared to adjacent non-disturbed areas. Monitoring techniques used as well as some typical results are shown in the paper.

\section{Introduction}

PT Freeport Indonesia, an affiliate of Freeport McMoRan Copper \& Gold operates a copper and gold mine in the province of Papua, Indonesia. While operation has been continuous since concentrate was first shipped in 1972, early mining of the Ertsberg deposit accounted for only minimal amounts of overburden placement. With the discovery and planned mining of the Grasberg deposit to produce around three billion tonnes of overburden, planning for large scale reclamation began in the early 1990s. Early research focused on identifying area plant species, determining the viability of transplanting representative species, and evaluating nutrient requirements in the planting mix. Relatively small test plots were prepared and monitored as overburden became available for the research. Concurrent with the reclamation research, geochemical evaluations and trials were in progress to determine feasible methods for managing potential 
acid generation from the overburden stockpiles. The results of these trials were the basis for Overburden Management Plans (OMP) and Five Year Reclamation Plans which are the guidelines for current operation. PTFI had a commitment from the permitting process to revegetate overburden areas as they became available. In the period of mine operation from 1996-2008, very few overburden areas were completed, and small spaces were carved out for additional testing, trials, and demonstration plots of revegetation techniques. Due to changes in mine plans or need for additional infrastructure about $40 \%$ of the area revegetated was 'decommissioned'. It was returned to mining or support operations so that at the end of the period the cumulative net reclaimed area was about 70 hectares. More recently, as overburden stockpile areas begin to reach capacity, additional area is available for reclamation and reclamation rates have been about 60 hectares per year. This paper focuses on the practical applications of techniques identified during the 1996-2008 trial period and lessons applied to current reclamation activities at the Grasberg open pit area.

\section{Background}

The Grasberg open pit operation is located in the Indonesian province of Papua on the western half of the island of New Guinea at an elevation of about 3,000-4,000 m. The location is shown in Figure 1.

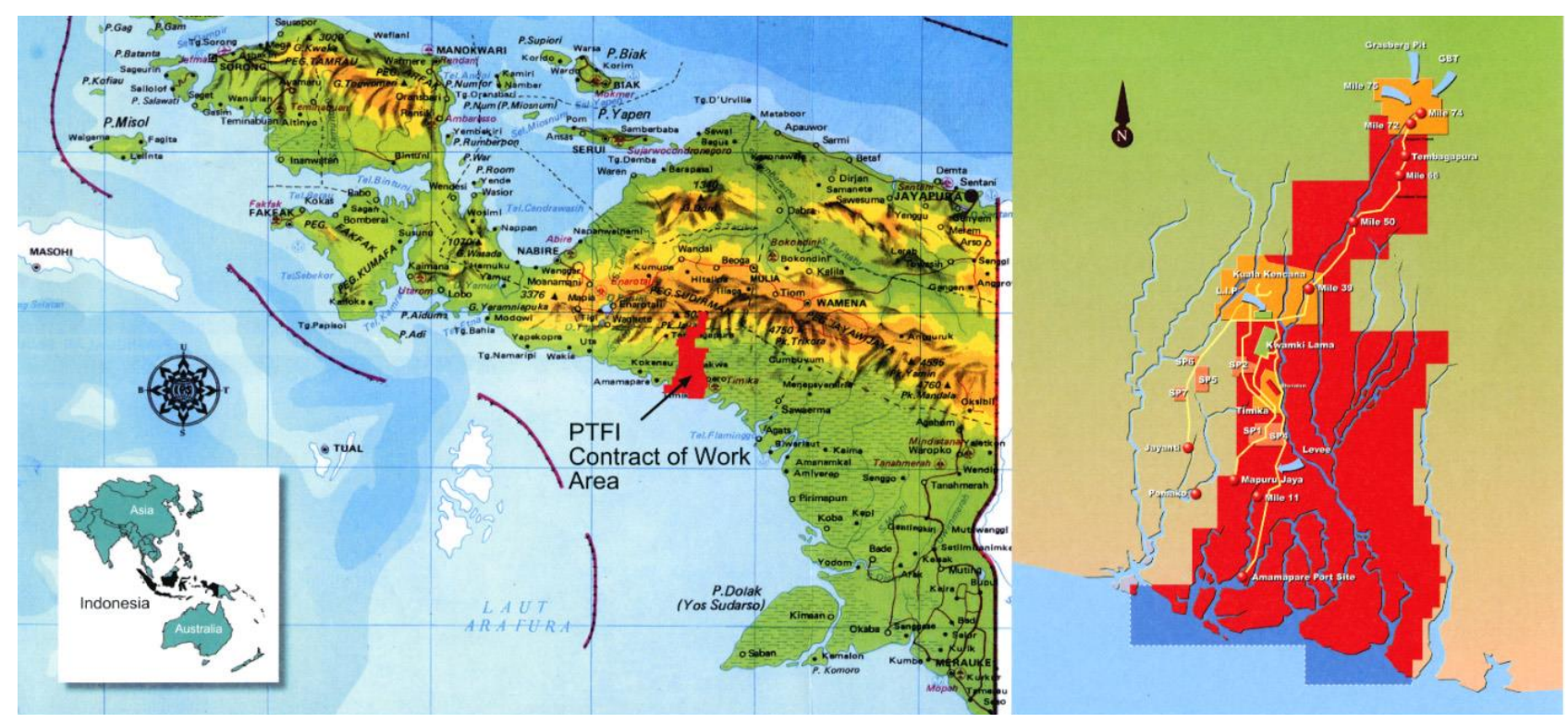

Figure 1 PTFI contract of work location

The climate in the area of the open pit mine is characterised by high rainfall and cool temperatures. PTFI's meteorological monitoring shows mean rainfall at the mine site of $2,819 \mathrm{~mm}$ per year and mean temperature of $6.8^{\circ} \mathrm{C}$. Due to the tropical location, there is little seasonal variability throughout the year. Rainy and foggy conditions are typical and there is occasional snowfall.

Mining of the Grasberg deposit began in 1989 and rates of mining have increased gradually since that time. As shown in Figure 2, total rates of ore feed to the mill gradually increased after 1989 to average around 200,000 tonnes per hour in the past dozen years. In recent years ore production rates from the pit have been about 160,000 TPD and overburden stockpiling rates have been about 550,000 TPD. Typical operation at the Grasberg pit includes 18 shovels and 155 haul trucks. The open pit is expected to continue in operation until sometime in 2017 after which time all the mine operation will be underground. 


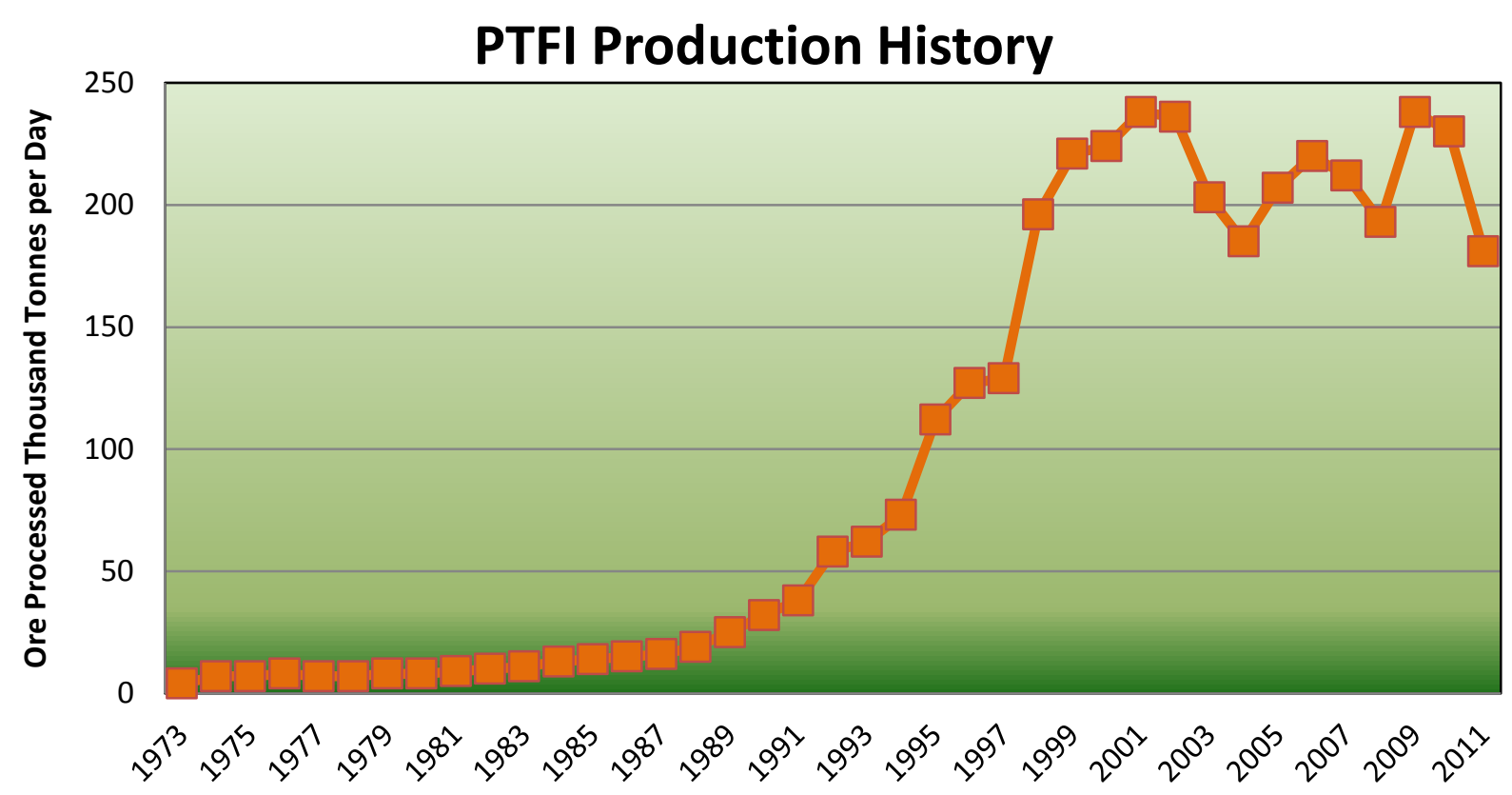

Figure 2 PTFI ore feed rates to mill

\section{Overburden management}

The overburden management process and key features are briefly described here as background to the ultimate overburden reclamation process.

Overburden management is controlled by an OMP that was prepared as a supplemental document to $300 \mathrm{~K}$ ANDAL (Analisis Dampak Lingkungan or Environmental Impact Assessment) (PT Freeport Indonesia, 1998) that was approved by the government of Indonesia. The plan was updated in 2006 to reflect changes in mining estimates of overburden volume and type, and results of research into acid rock drainage (ARD) mitigation and management. The purpose of the OMP is to provide the guidance and management tools necessary to effectively mine overburden rock from the Grasberg open pit and place it in engineered overburden stockpiles with minimal long-term safety, environmental and geotechnical impacts. Figure 3 shows the general planned layout of the overburden stockpiles.

Some of the key objectives of the plan are to ensure that throughout the operation, closure and beyond:

- Overburden stockpiles will be geotechnically stable.

- Adequate surface drainage will be provided and erosion minimised.

- ARD formation will be mitigated, collected and/or treated to minimise impacts to surface water and groundwater quality.

- Limestone rock will be effectively used to mitigate ARD and ensure stockpile geotechnical stability.

- Heavy sulfide zone material will be selectively mined and segregated to facilitate ARD collection.

- Where applicable, overburden stockpile final surfaces will be prepared to facilitate reclamation.

To support these objectives, the rock types present in the deposit were grouped geotechnically based on hardness or geochemically by the potential to form acid rock drainage. 


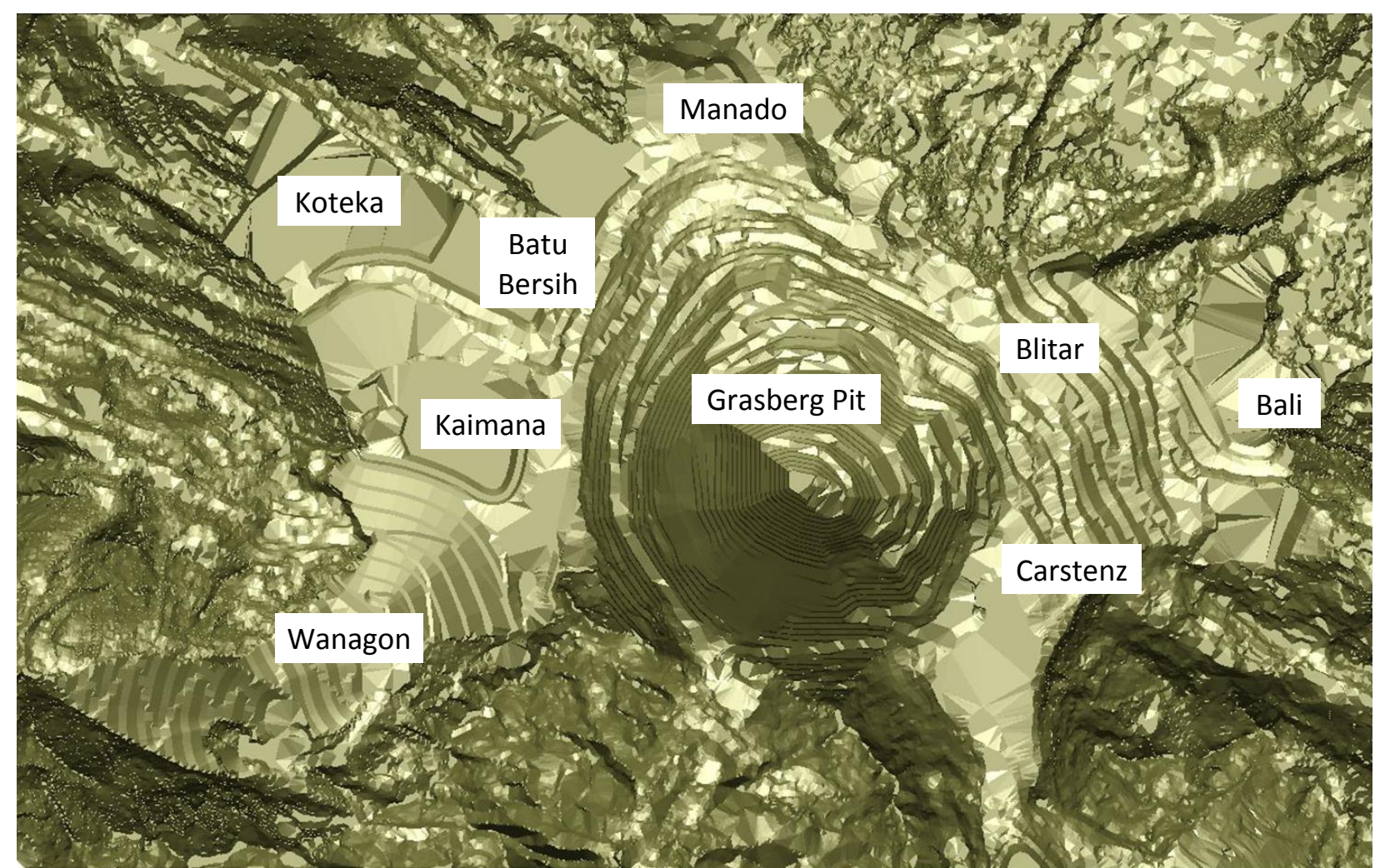

Figure 3 Grasberg overburden stockpile plan view

Geotechnical engineers design the stockpiles to be stable based on site-specific criteria taking the rock characteristics into account. Stockpile construction is controlled to provide the proper geometry as well as foundation loading. Buttressing the stockpile toe against natural topography is used where applicable. The blend ratios of fine and coarse material are controlled and, in some cases, coarse rock drains are constructed underneath the stockpiles to maintain desired phreatic water levels. Geotechnical monitoring systems using extensometers, prisms, radar systems, inclinometers, and other instrumentation is in place to ensure the stability of the stockpiles.

Seven categories of rock types were established based on their Net Acid Generating (NAG) potential. These categories were then grouped into four colour codes for management purposes. Acid consuming or nonacid forming rock is coded green, low to moderate acid forming rock is coded blue, high or very high acid forming rock is considered red waste, and rock containing more than $20 \%$ pyrite is considered heavy sulphide zone (HSZ) material. The overburden management plan uses a combination of segregation and blending to control future ARD generation from the overburden stockpiles. Where blending is not adequate to control future ARD generation, a five metre cap of limestone is used on the final surface to mitigate future ARD generation. Monitoring of early ARD test plots and of the actual stockpile runoff water has demonstrated that these controls have been effective.

The OMP also provides for final preparation of the stockpiles prior to revegetation activities such as provision for drainage and runoff collection or provision for access or restricting access as appropriate.

\section{$4 \quad$ Reclamation research}

Reclamation research related to the Grasberg Mine has focused on gathering baseline information on area flora and fauna, determining candidates for reclamation planting, evaluating methods of transplanting and the viability of the transplants, and determining nutrient requirements.

Significant vegetative surveys of the area were conducted by researchers such as Beak Pacific (Beak Pacific Inc., 1996), Kew Royal Botanical Gardens (Kew Royal Botanical Gardens, 2000), and PT Hatfindo 
(PT Hatfindo and PT Freeport Indonesia, 1997-1998) which generated extensive catalogues of vegetation present in the PTFI project area. These works were used to guide the selection of plants for reclamation programs to ensure appropriate representation of local species and assist in re-establishing biodiversity.

One early study (Miller, 1991b) was concerned with whether there were any unique plants in the Carstensz Meadow, which was the area of the future Grasberg open pit, and with the determination of a similarity index as requested by the government of Indonesia to compare the flora of the Carstensz Meadow with neighbouring valleys. The study built upon earlier work (Hope, 1976) which reported on results of expeditions in the 1971-1973 time period. The conclusions included that "study of collections revealed no species which would be considered to represent a truly unusual habitat type within the context of tropic alpine meadows of the Carstensz Mountains" (Miller, 1991b).

The same researcher, Dr. Harvey A. Miller, proposed a general reclamation plan for the area studied (Miller, 1991a). His recommendation was to use native vegetation with the dominant tussock grasses as the key component and supplemented by other seeds and propagules of native plants and shrubs. The intent was to create microhabitats that would encourage recruitment of seeds of other native plants to accelerate the establishment of a diverse plant cover. Test plots using transplanted Deschampsia Klossii during that time had demonstrated that the plants could survive transplanting.

A somewhat more detailed reclamation program was prepared (Golder Associates Inc., 1997). This document laid out some preliminary recommendations regarding nutrient additions and identified a potential problem with seed viability using the native Deschampsia Klossii in hydroseeding mixes. Alternates proposed included using commercially available annual or sterile hybrid seeds or seeds of commercially available analogues of Deschampsia Klossii such as Deschampsia Caespitosa. The purpose of using either of these alternates would be to more quickly establish a vegetative erosion protection cover which could eventually be replaced by natural succession and transplanting by native plants. The use of commercially available sterile hybrid seeds was trialled on a one hectare slope in 1997. The objective of an early vegetative erosion protection was achieved and an evaluation 10 years later concluded that the originally planted sterile hybrid species was no longer present and was being replaced by native grasses.

Other researchers studied the viability of additional locally available plants for transplanting such as rhododendrons (PT Hatfindo Prima, 2001) and tree ferns (Johns and Hidayata, 1999). Several locally available rhododendron species were shown to thrive on transplanting. Tree ferns survived to provide ground cover for the reestablishment of other species, but their regeneration rate has been slow in practice.

An ethnobotany study was carried out in 2000 by PTFI and PT Hatfindo (Shea et al., 2006) and published in booklet form by PTFI in 2006. This study identified native plants in the Grasberg with significant traditional uses by the local community. These plants were also targeted to be transplanted in the reclamation program to ensure their long-term availability.

Additional research (Hort Research, 2001) was conducted into using mosses as pioneer plants, especially in the hydroseeding mix. The purpose of the mosses is to assist in initial cover and in soil development on the rock surfaces. Several species of mosses native to the area were successfully tested in those trials.

Another potential barrier to successful revegetation was the lack of topsoil. While there was a topsoil conservation and stockpiling program in the initial mine operation, this material was consumed in early reclamation test plots and demonstrations so that little to no topsoil is available at the mine site for current reclamation efforts. Research was initiated into the use of other materials, one of which is limestone fines. PTFI operates a limestone quarry adjacent to the Grasberg open pit to produce limestone for the mill operation. The fine material fraction from the limestone crusher operation was tested by site personnel beginning in 2001 as a substitute for topsoil in transplanting operations.

Tissue culture techniques have also been tested as an alternate to collecting seedlings from the surrounding area. Previous work has not been encouraging, however a current program is underway in 
cooperation with the Agricultural Institute (IPB) in Bogor and initial results are planned to be released shortly.

\section{$5 \quad$ Reclamation planning}

PTFI is committed as part of the 300K ANDAL to reclaim overburden stockpile areas as soon as they become available. The planned reclamation is documented in five year reclamation plans that are submitted to the Government of Indonesia (GOI). These plans cover all reclamation from the mine area to the estuary and include maps showing areas to be reclaimed, number of hectares planned, and the budgeted expenditures for reclamation. The budgeted amounts are guaranteed to the $\mathrm{GOI}$ and funds are released based on inspections to verify successful reclamation. In the early years of Grasberg open pit operation areas that became available were small and somewhat scattered. In fact, as mentioned in the introduction, only a net 70 ha were reclaimed through 2008. The current five year plan covers the years 2009-2013 and projected 325 ha to be reclaimed during the period. The chart shown as Figure 4 demonstrates that only relatively small areas were reclaimed up to 2007 due to the slow progression of areas available for reclamation. The figure also demonstrates the impact of changes in mine plans resulting in a net negative amount reclaimed in the year 2005. After 2007 as some overburden stockpile areas have reached their capacities, more hectares are available and are being reclaimed accordingly. The research trials discussed above were carried out during the period when only small areas were available for reclamation work.

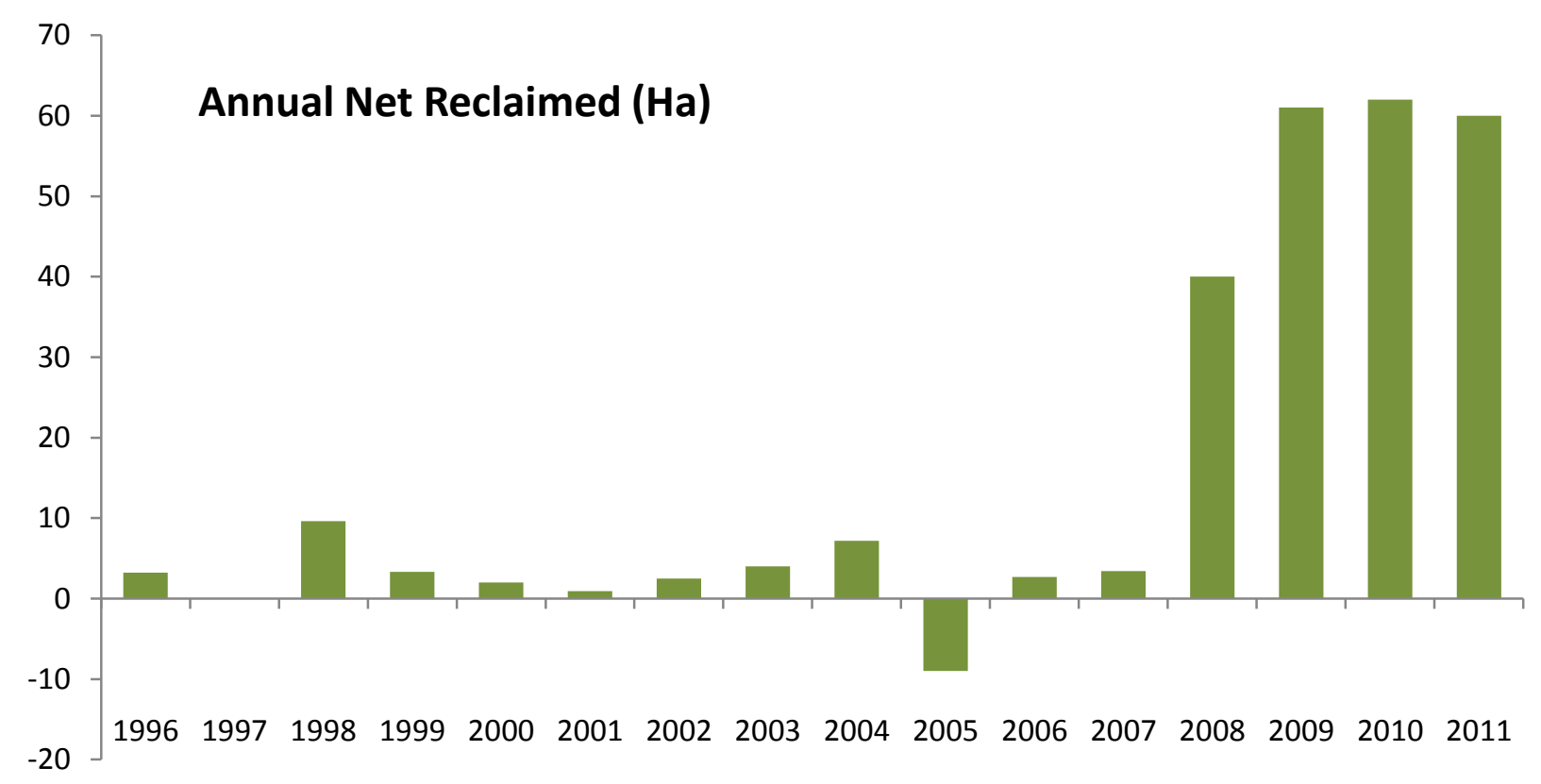

\section{Figure 4 Net annual reclamation at the Grasberg open pit}

Figure 5 shows the location of the areas reclaimed to date as cross-hatched. It can be seen that much of the available area to date has been on slopes and the only large relatively flat area that represents a stockpile area at capacity is to the north of the open pit.

\section{Current practices in revegetation}

Consistent with the research summarised above, ongoing reclamation is carried out according to the five year reclamation plan. 


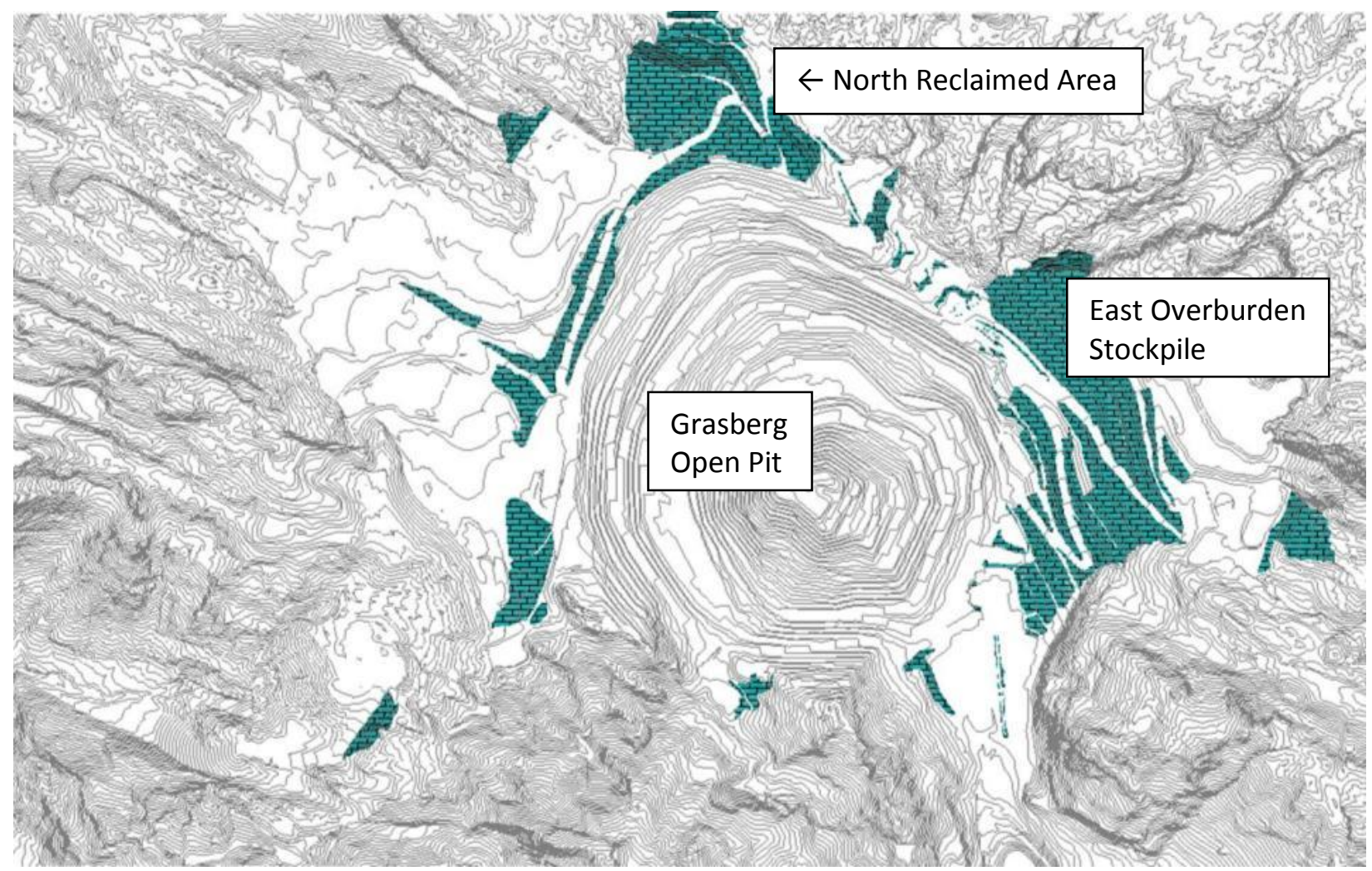

Figure 5 Location of reclaimed areas

\subsection{Harvesting native plants}

The primary plant type used has been the native tuft grasses such as Deschampsia Klossii. This grass was the most prevalent in the area pre-mining and is the most abundant in the surrounding area. It is hardy and thrives in the conditions existing at Grasberg. Its seeds are harvested for use in hydroseeding and full clumps are taken for further processing in the nursery. In addition to the plants in the surrounding area, an area near the nursery planted in these grasses is now also used as a seed orchard.

Shrubs identified in the earlier research are also harvested from the surrounding, relatively undisturbed areas. These include anaphalis hellwigii, rhododendron sp., rhododendron correoides, rhododendron gaultherifolium, olearia lepidota, olearia velurtina, and others. Tree ferns are harvested to a lesser extent than the smaller shrubs. Figure 6 demonstrates the harvesting process and shows a few of the shrubs gathered.

Mosses of several species are also harvested and used both in direct transplanting and in the hydroseeding process.

\subsection{Nursery operation}

A plant nursery is operated near the open pit for preparing the harvested plants for transplanting. Grass clumps are subdivided and replanted in pots containing a mix of compost and soil. The pots may be organic pots produced from coconut fibre-coco pots or pots made from polyethylene. The coco pots are more manageable in the field, especially on steep slopes, and have the advantage of being organic so that the plant roots eventually grow through them into the substrate. Shrubs are usually placed in larger coco pots. When they are used, tree ferns are moved directly from the harvest location to the replanting site without going through the nursery process.

The compost used in the pots is produced onsite from mess hall waste, grass clippings, sawdust, or other sources and is supplemented by purchased compost. The soil is used in small amounts and helps introduce seeds or seedlings of plants in addition to the specific seedling being transplanted. About 12 tons of 
compost is required to set up transplants for one hectare of reclamation. Slow release commercial fertilisers are also added to the mix to supplement nutrients available in the compost/soil mix.

After the plants are set up in the pots, they are placed outside the nursery building directly on the ground and allowed to grow in the pots and acclimate to the conditions. They are watered if necessary. The acclimation time is on the order of two months, depending on the planting schedule.
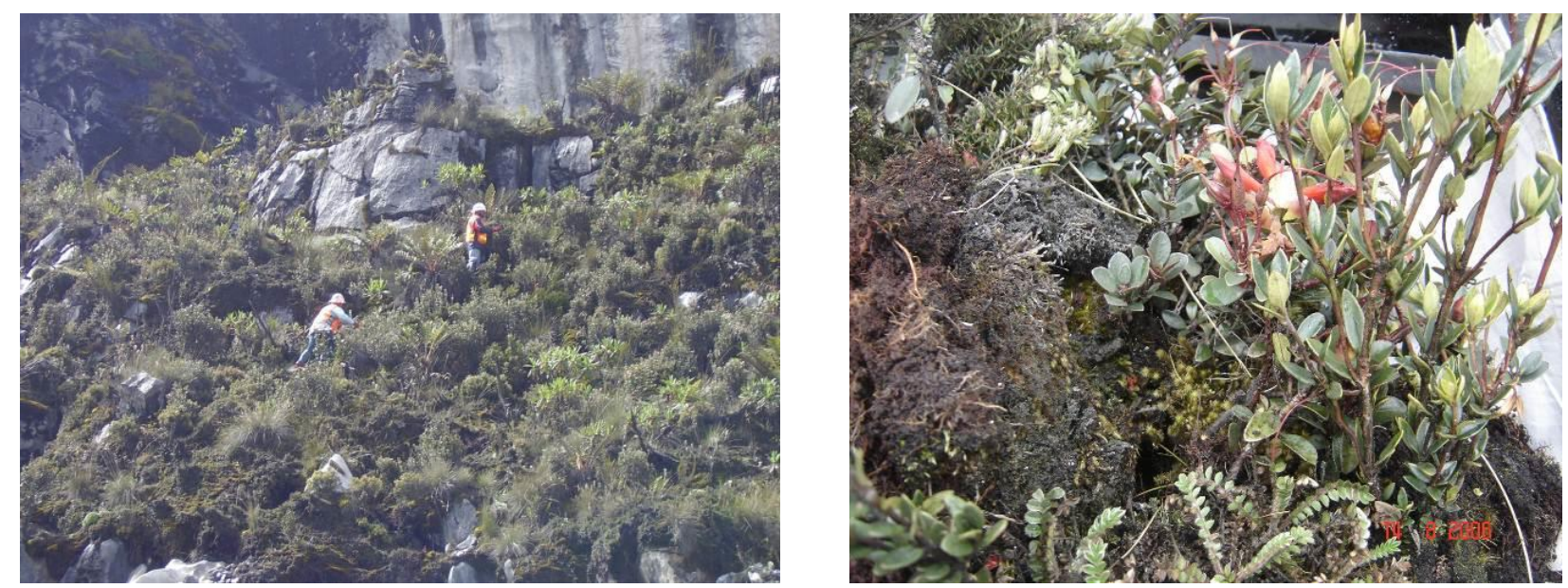

Figure 6 Gathering shrubs for reclamation. On right are Tetramolopium klosii, Rhododendron verteegii, Rapanea communis, Racometrium sp., Potentilla sp.
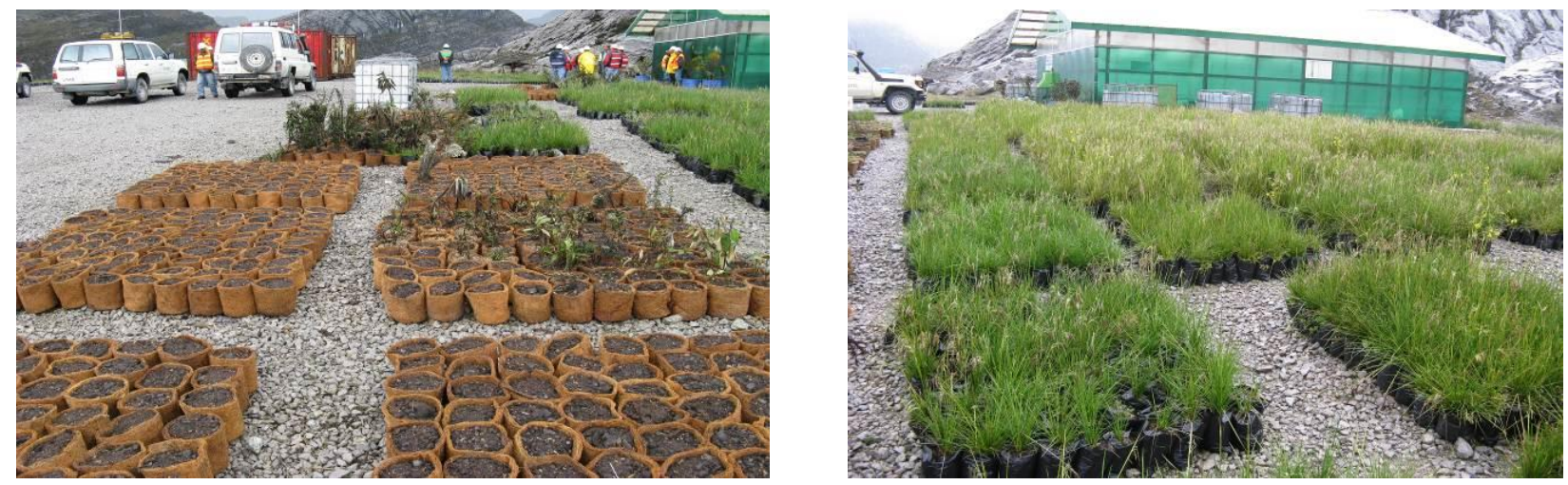

\section{Figure 7 Plants in acclimation phase at the nursery site}

\subsection{Transplanting techniques}

As mentioned, limestone fines were tested as a substitute for topsoil to enable transplanting. Limestone of about $90 \%$ purity is mined in a quarry adjacent to the Grasberg open pit and crushed to supply a calcining plant for the production of quicklime used in the concentrating process. The fines are available because the size fraction is not suitable for the concentrator. They are placed onto the area to be revegetated and spread using a small dozer to a nominal $15 \mathrm{~cm}$ layer. These crushed rock fines obviously have little to no nutrient value and serve only as a mechanical aid to placement of the transplants. They hold the pots in place until a root system can be established. It has also been observed that recruitment of other plants including mosses is enhanced by the use of the limestone fines layer. Figure 8 shows a newly planted surface with the limestone fines layer evident in the foreground.

A spacing of two metres between plants is used in the initial planting resulting in a requirement for 2,500 plants per hectare revegetated. The Deschampsia Klossii grasses are the predominant plants used for initial cover. They survive at essentially a $100 \%$ rate and thrive in the sub-alpine and alpine environments. As the tussocks grow, the structure of the grasses provides shelter for emerging seeds that arrive naturally or with assistance (Miller, 1991a). The plants are also described as viviparous since the seeds germinate on 
the plant before falling to the ground. This adaptation to the cold climate assists the grasses in spreading to the areas between the transplants (Shea et al., 2006).

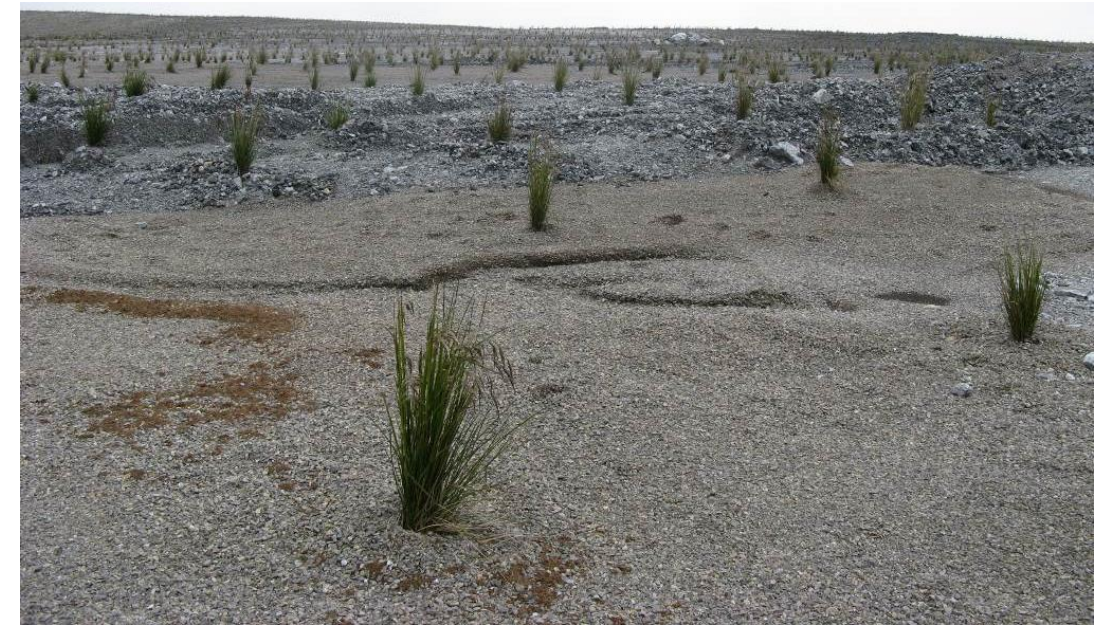

\section{Figure 8 Limestone fines to aid transplanting}

The process of using compost mixed with small amounts of topsoil in the nursery results in other native plants being present along with the Deschampsia Klossii. The combination of seed production from the transplants, natural recruitment, additional plants arising from the topsoil source, and additional moss and nutrients spread in the spaces between the transplants allows the surfaces to fill in over time as shown in Figure 9. This process usually requires about three years to become well established.

In addition to the grass establishment, shrubs are also planted to enhance the biodiversity within the reclaimed areas. These are sometimes planted as individual specimens, and sometimes as groups of shrubs to create a microclimate to attract fauna in the area.
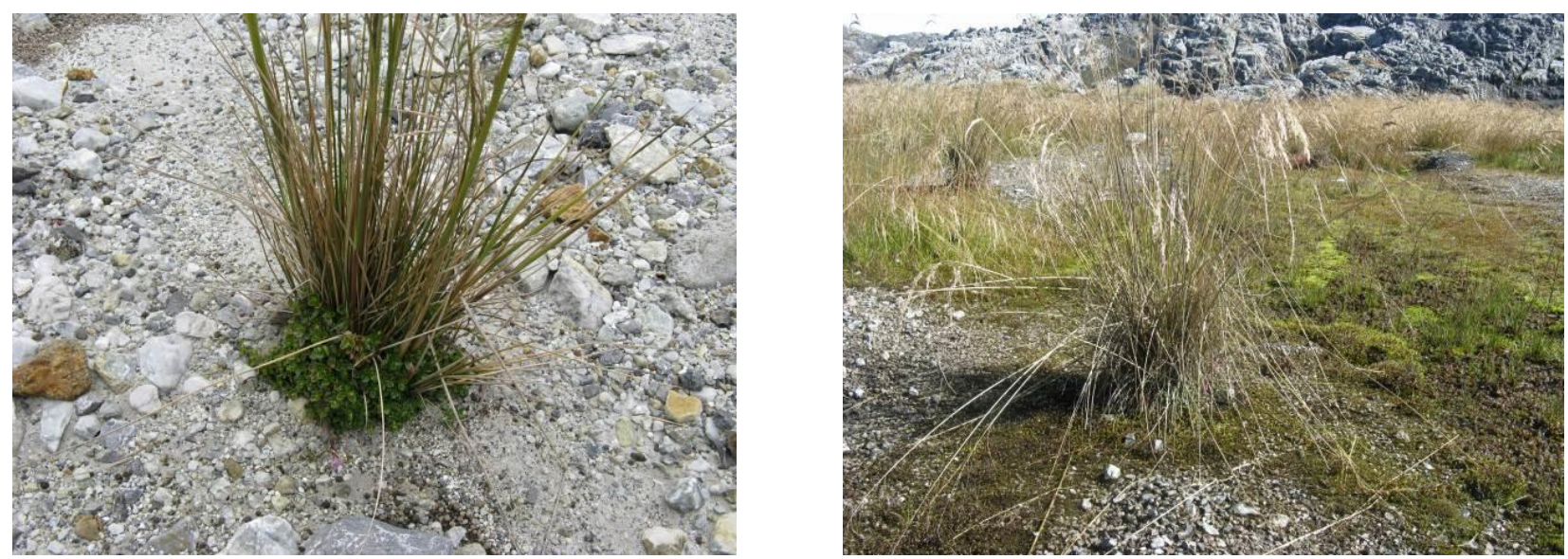

\section{Figure 9 Secondary plants and further growth}

The above description also applies generally to sloped areas to be revegetated, but additional considerations apply. The primary considerations are safety of personnel working on the slopes and additional erosion protection where necessary.

The personnel performing transplanting on the steep slopes which are generally at angle of repose are required to use rope systems for fall protection. They receive the same training as the emergency response group personnel in the application of the rope systems including care and maintenance of the equipment.

In some cases where the slope has been over steepened or undercut by mining support operations or where the slope surface consists of large boulders the typical limestone fines application is not suitable and additional materials must be taken into consideration. In those places, jute net is used to cover the slope to 
provide a base for plant establishment. Usually these jute net covered slopes are hydroseeded only. Figures 10 and 11 show these two situations.

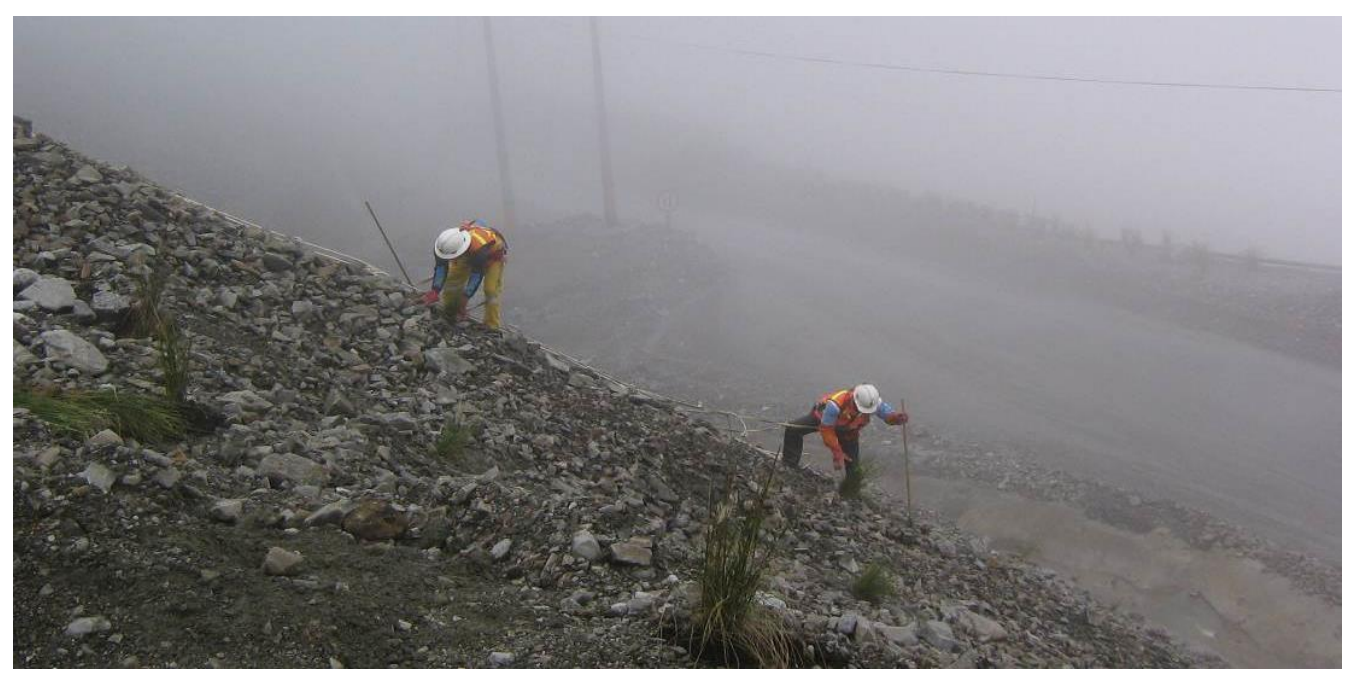

\section{Figure 10 Rope fall protection for transplanting on slopes}

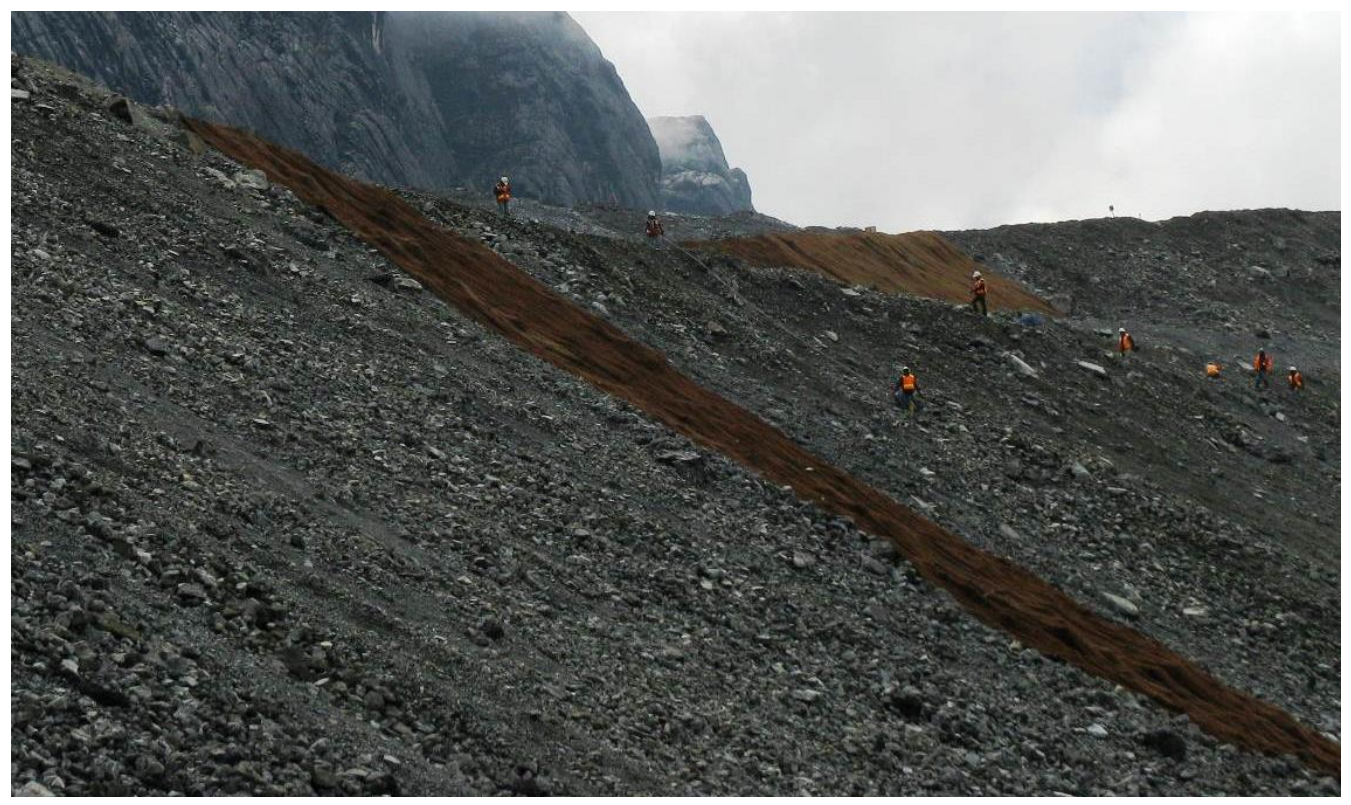

\section{Figure 11 Jute net placement on slopes}

\subsection{Hydroseeding}

Hydroseeding can be used to establish a vegetative erosion cover to supplement the transplanting practice. As noted in the preceding section, hydroseeding is especially helpful to establish vegetation on sloped surfaces. The hydroseeding mix that has been used at Grasberg contains several nutrients, germination accelerants, tackifiers, and mulch as is typical of most commercial hydroseeding applications. At Grasberg, we also add finely chopped mosses in varying amounts.

Table 1 shows a typical mix used in the hydroseeder. Specific materials may change due to availability or pricing of competing ingredients. The balance is water from surface sources at the mine. The quantities are given on a per tank basis and approximately three tank loads are required per hectare of surface area to be hydroseeded. To date the hydroseeding has been done using a unit mounted on a flatbed truck, but it is being replaced this year by a trailer mounted unit that can be towed by light equipment such as a four wheel drive truck or farm tractor. Operating from access roads or benches, the machine can spray the mixture up to $100 \mathrm{~m}$, depending on conditions. 
Table 1 Hydroseeding recipe

\begin{tabular}{lcc}
\hline Ingredient & Unit & $\begin{array}{c}\text { Application Per } \\
\text { Tank Load }\end{array}$ \\
\hline Domestic fiber mulch & Bag $(20 \mathrm{~kg})$ & 20 \\
Imported mulch & Bag $(20 \mathrm{~kg})$ & 9 \\
Seed & $\mathrm{Kg}$ & 15 \\
Tackifier & $\mathrm{Kg}$ & 7 \\
Organic fertiliser & $\mathrm{Kg}$ & 10 \\
NPK 16,16,16 & $\mathrm{Kg}$ & 20 \\
Biosol fertiliser & $\mathrm{Kg}$ & 40 \\
Alcosorbs & $\mathrm{Kg}$ & 2 \\
Seed starter & Litre & 1 \\
Wetting agent & Litre & 1 \\
Green dye & $\mathrm{Kg}$ & 1 \\
\hline
\end{tabular}

The seeds in the hydroseeding mix are those from the native grasses and are harvested locally. Even though the native grasses are prolific seed producers, collecting and preserving an adequate supply of viable seeds in the moist climate of Grasberg does present challenges. Two alternates have been considered based on the prior research.

The first alternate considered was a commercial product which is sold as a sterile hybrid. It is intended to establish an initial vegetative layer on the ground surface and later to be replaced by native plants that are better suited to the environment. As mentioned earlier, a trial was conducted using these seeds in 1997 and the stated purpose was achieved. However, PTFI is still cautious about using this sterile hybrid technology and has not applied it on a larger scale.

The second alternate is to use seeds of commercially available analogues of Deschampsia Klossii such as Deschampsia Caespitosa (Golder Associates Inc., 1997). This species is extremely similar to Deschampsia Klossii and is present in similar altitudes throughout the world. Its seeds are commercially available as it is used widely in reclamation in the United States intermountain region. At this writing, PTFI is pursuing GOI approval to import Deschampsia Caespitosa seeds to Papua in order to increase the productivity of the hydroseeding operations.

\subsection{Reclamation monitoring}

Monitoring is conducted to evaluate the effectiveness of the reclamation activities in establishing initial vegetative cover, determine additional nutrient requirements, and evaluate the development of biodiversity in the reclaimed areas.

Visual observation is made for the presence of erosion gullies or significant sheet erosion, condition of drainage systems, soil development, presence of a variety of plants including traditional use plants, health of vascular plants and moss cover, absence of weeds, degree of surface cover in flat areas and on slopes, and evidence of regeneration and natural succession taking place.

Soil samples are taken to evaluate the need for additional nutrients. Samples are taken in years one, two and five at a spacing of about 0.7 samples per hectare. Soil analysis is done at an off-site lab and results are used for planning of additional fertiliser applications.

Biodiversity evaluation beyond the visual checklist is a continuing programme onsite. The target is to ultimately achieve biodiversity in the reclaimed areas that is similar to that in undisturbed areas in the 
same general elevation. To this end, reference plots were established during the earlier research period. In the flora biodiversity evaluation, the Shannon-Weaver biodiversity index values for these reference plots are compared to four meter by four meter test plots within the reclamation areas. The index is calculated as (Raytheon Employees Wildlife Habitat Committee, 1999-2000):

$$
H^{\prime}=-\sum p_{i} \ln \left(p_{i}\right)
$$

Where:
$H^{\prime} \quad=\quad$ the Shannon-Weaver Index.
$p_{i} \quad=\quad$ the relative abundance of each type of plant.

The measurements are made on an approximately annual basis. Typical data from a few of these plots is shown in Figure 12. In this figure, the DOM reference plot is shown along with three reclamation sites. The chart shows a reasonably similar index when comparing the reclamation sites to the reference plot and a general increase in measured biodiversity over time.

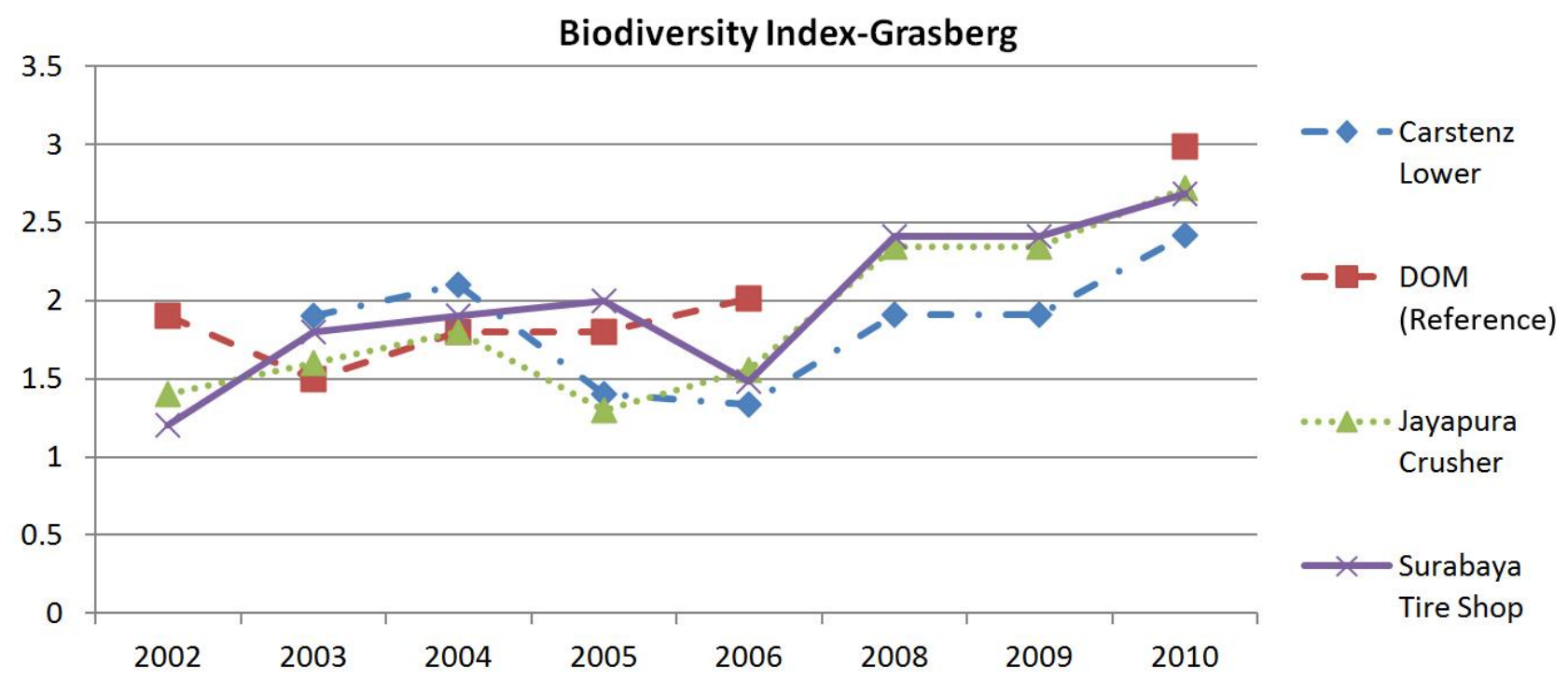

Figure 12 Flora biodiversity measurements

Runoff water quality is also a component of evaluating the success of the reclamation program. Test plots have been used to evaluate the effectiveness of the various cover alternates in reducing erosion. Large scale runoff water quality has not been significantly affected by the reclamation to date since the reclamation is surrounded by the active mine site. Total Suspended Solids (TSS) and pH are measured weekly at two points representing runoff from the east and west portions of the overburden stockpiles, but these points are more highly influenced by the effectiveness of the mine operation sediment traps than the limited reclaimed areas.

\section{Conclusion}

Every mine reclamation site presents its own challenges to the operator. At Grasberg the challenges include the elevation, the high rainfall environment, cool temperatures, lack of available topsoil and the logistical difficulties associated with its location. Research during the first 10 or so years of the Grasberg open pit operation has been invaluable in developing effective techniques for overburden stockpile reclamation onsite. Initial results of the reclamation program have demonstrated viable plant cover and a reasonable biodiversity. Continued monitoring will be required to ensure the long term effectiveness of this program. 


\section{References}

Beak Pacific Inc. (1996) Report No. 7A: Review of Vegetation for Reclamation Uses at High Elevation Minesites, Beak Pacific Inc., Vancouver, BC, Canada.

Golder Associates Inc. (1997) Preliminary Plan for the Reclamation of Mine Overburden and Mill Tailings at PT Freeport Indonesia Company Operations, Irian Jaya, July 1997, Golder Associates Inc., Lakewood, CO, USA.

Hope, G.S. (1976) The Equatorial Glaciers of New Guinea: Results of the 1971-1973 Australian Universities' Expeditions to Irian Jaya: Survey, Glaciology, Meterology, Biology and Palaeoenvironments, J. A. Peterson, U. Radok and I. Allison (eds), A.A. Balkema, Rotterdam.

Hort Research (2001) Developing Protocols for Utilising Moss in Revegetation of the Grasberg Overburden, Hort Research, Motueka, NZ.

Johns, R.J. and Hidayata, A. (1999) Report on the Species Trials on Consolidated Overburden at Carstenz Meadow, The Royal Botanical Gardens, Richmond, Surrey, UK.

Kew Royal Botanical Gardens (2000) A Preliminary Checklist of the Alpine and Subalpine Flora of Puncak Jaya, The Royal Botanical Gardens, Richmond, Surrey, UK.

Miller, H.A. (1991a) Development of a Reclamation Plan for the Carstenszweide Overburden, Lotspiech and Associates Inc., Winter Park, Florida, USA.

Miller, H.A. (1991b) A Botanical Study of the Carstenz Meadow and Other Meadows in the Area Irain Haya, Lotspiech and Associates Inc., Winter Park, Florida, USA.

PT Freeport Indonesia (1998) PTFI 300K Expansion Final Regional ANDAL, PT Freeport Indonesia, Jakarta, Indonesia.

PT Hatfindo and PT Freeport Indonesia (1997-1998) Biodiversity Surveys in the PT Freeport Indonesia Contract of Work Mining and Project Area, Mimika Regency, Irian Jaya, Indonesia, PT Freeport Indonesia, Environmental Department, Jakarta, Indonesia.

PT Hatfindo Prima (2001) Biodiversity and Ecophysiology of Rhododendrons for Overburden Restoration, PT Hatfindo Prima, Bogor, Indonesia.

Raytheon Employees Wildlife Habitat Committee (1999-2000), Biodiversity Measures, viewed 26 June 2012, http://rewhc.org/biomeasures.shtml.

Shea, G., Sarosa, W. and Uamang, P. (2006) Knowing our Mine Environment, Ethnobotany of Subalpine and Alpine Plants on Mt Jaya, PT Freeport Indonesia, Jakarta, Indonesia. 
